\title{
MENINGKATKAN PRESTASI BELAJAR MATEMATIKA DENGAN MENGOPTIMALIKAN MODEL PEMBELAJARAN PROBLEM SOLVING SISWA KELAS VIII A SMP WIDYA SAKTI DENPASAR
}

\section{IMPROVE MATHEMATICS LEARNING ACHIEVEMENT BY OPTIMIZING THE PROBLEM SOLVING LEARNING MODEL FOR CLASS VIII A SMP WIDYA SAKTI DENPASAR}

\author{
I Wayan Nendra* \\ SMP Widya Sakti Denpasar, Denpasar, Bali, Indonesia \\ *Email Penulis korespondensi: nendraiwayan@gmail.co.id
}

\begin{abstract}
Abstrak
Penelitian ini bertujuan untuk meningkatkan prestasi belajar matematika siswa dengan mengoptimalkan model pembelajaran Problem Solving dalam proses pembelajaran. Subjek penelitiannya adalah kelas VIII A SMP Widya Sakti Denpasar pada mata pelajaran matematika semester I tahun pelajaran 2019/2020 yang berjumlah 39 orang siswa. Data yang dikumpulkan adalah data kuantitatif berupa hasil belajar yang dikumpulkan menggunakan instrumen tes. Hasil yang diperoleh di analisis dengan analisis deskriptif. Setelah berakhir melakukan analisis data diketahui bahwa peningkatan prestasi belajar sudah dapat diupayakan. Hal tersebut terbukti dari kenaikan nilai siswa dari rata-rata awal 70,97 dengan ketuntasan belajar 38,46\% pada siklus I meningkat menjadi 74,77 dengan ketuntasan belajar 76,92\% dan pada siklus II sudah meningkat menjadi 81,46 dengan ketuntasan belajar 100\%. Data tersebut menuntut peneliti untuk membuat simpulan bahwa prestasi belajar matematika dapat ditingkatkan dengan mengoptimalkan model pembelajaran Problem Solving pada siswa di kelas VIII A SMP Widya Sakti Denpasar.
\end{abstract}

Kata-Kata Kunci: Prestasi Belajar; Model Pembelajaran Problem Solving

\begin{abstract}
This study aims to improve students' mathematics learning achievement by optimizing the Problem Solving learning model in the learning process. The research subject is class VIII A SMP Widya Sakti Denpasar in the first semester of mathematics subjects for the 2019/2020 school year, totaling 39 students. The data collected is quantitative data in the form of learning outcomes collected using test instruments. The results obtained were analyzed by descriptive analysis. After completing the data analysis, it is known that the improvement of learning achievement can be pursued. This is evident from the increase in student scores from the initial average of 70.97 with $38.46 \%$ learning completeness in the first cycle increasing to 74.77 with $76.92 \%$ learning completeness and in the second cycle it has increased to 81.46 with learning mastery $100 \%$. These data require researchers to conclude that mathematics learning achievement can be improved by optimizing the Problem Solving learning model for students in class VIII A SMP Widya Sakti Denpasar.
\end{abstract}

Keywords: Learning Achievement; Problem Solving Learning Model

\section{PENDAHULUAN}

Tujuan pendidikan pada dasarnya adalah hendak mewujudkan tujuan hidup manusia. Tujuan hidup tersebut adalah dapat berkembang secara optimal perikehidupan sesuai hakekat manusia, dimensi kemanusiaan dan pancadaya. Seperti yang dinyatakan Prayitno (2009: 44) bahwa tujuan pendidikan mengarah pada berkembangnya daya cipta, rasa, karsa, takwa, dan karya setiap individu atau perkembangan unsur-unsur hakekat manusia yang bertakwa kepada Tuhan Yang Maha Kuasa, sesuai keindahan, kesempurnaan dan ketinggian derajatnya, memelihara alam tempat tinggalnya, dan terpenuhinya hak-hak asasinya. 
Agar peserta didik menjalani proses pembelajaran dalam suasana maju berkelanjutan, pendidik perlu aktif menetapkan target-target pembelajaran, merentang jalan dan mengembangkan suasana bagi kehangatan dan kegairahan peserta didik meraih satu demi satu target pembelajaran tersebut. Jika diperlukan bahkan pendidik membangun jembatan dan merintis titian agar peserta didik dapat menyebrangi riak dan menembus rintangan untuk mencapai target yang perlu digapai dan diraihnya. Jalan atau pola maju berkelanjutan dalam pengelolaan proses pembelajaran setiap kali harus disesuaikan dengan kemampuan dasar dan kondisi kemajuan yang diperoleh peserta didik dari waktu ke waktu. Pengembangan suasana pembelajaran yang memungkinkan maju berkelanjutan bagi peserta didik sangat memerlukan penerapan kewibawaan dan kewiyataan oleh pendidik (Prayitno, 2009: 44).

Masalah sering dihadapi guru dalam proses pembelajaran dikarenakan apa yang diharapkan, dipahami dan dikuasi guru tidak dijalankan secara optimal. Terkadang akibat suasana hati yang tidak nyaman karena permasalahan keluarga membuat tugas guru tidak dijalankan dengan baik. Akibatnya, seperti yang sedang dihadapi saat ini di kelas VIII A di SMP Widya Sakti Denpasar betul-betul merupakan masalah pembelajaran dimana siswa di kelas ini belum aktif belajar mereka lebih bersifat menunggu, mereka lemah dalam menganalisa dan mencerna materi. Oleh karenanya, guru mulai memikirkan cara untuk memecahkan masalah yang sedang dihadapi. Prestasi belajar matematika siswa kelas VIII A di SMP Widya Sakti Denpasar pada semester I tahun pelajaran 2019/2020 masih jauh di bawah KKM mata pelajaran matematika di sekolah ini yaitu 75,00. Rata-rata yang diperoleh siswa baru mencapai 70,97 dan ketuntasan belajar mereka hanya 38,46\%.

Perolehan hasil yang rendah tersebut merupakan masalah yang sesegera mungkin harus ditangani, itulah yang mendorong peneliti sehingga penelitian ini menjadi penting untuk dilaksanakan. Guna mencapai hasil oleh kreativitas yang maksimal, maka guru dituntut agar lebih tepat dalam menulis dan menentukan media, metode, model, strategi, pendekatan dan teknik yang digunakan dalam melaksanakan proses belajar mengajar. Yang tidak kalah penting juga adalah dikuasai atau tidaknya materi pelajaran yang diajar. Dengan kata lain sebagai guru, ternyata ada tuntutan untuk berolah kreativitas secara langsung di hadapan siswa.

Alternatif pemilihan strategi dan metode pembelajaran yang akan diterapkan guru sesuai dengan materi ajar yang diampu adalah dengan mengoptimalkan model pembelajaran Problem Solving. Model tersebut sesuai teori mampu untuk mengantarkan siswa agar mengerti dan memahami materi pelajaran yang disampaikan guru. Tidak hanya itu, dengan strategi tersebut juga akan memberikan pengalaman berharga bagi siswa untuk mengenal dan mempraktekkannya dalam kehidupan sehari-hari.

Mengacu pada apa yang dipaparkan dalam latar belakang, maka rumusan masalah yang dapat disampaikan: Apakah prestasi belajar matematika dapat ditingkatkan dengan mengoptimalkan model pembelajaran Problem Solving pada siswa kelas VIII A semester I SMP Widya Sakti Denpasar tahun pelajaran 2019/2020? Dari rumusan yang disampaikan, maka tujuan penelitian ini dapat dijelaskan sebagai berikut: Untuk mengetahui seberapa tinggi peningkatan prestasi belajar matematika siswa akan terjadi setelah mengoptimalkan model pembelajaran Problem Solving pada siswa kelas VIII A Semester I SMP Widya Sakti Denpasar Tahun Pelajaran 2019/2020.

Manfaat hasil penelitian secara teoritis sebagai acuan dalam memperkaya teori dalam rangka peningkatan kompetensi guru. Sedangkan secara praktis penelitian ini diharapkan bermanfaat: 1) bagi siswa, akan mengenal model pembelajaran Problem Solving; 2) bagi guru, akan mampu melaksanakan model pembelajaran Problem Solving; 3) bagi sekolah, sebagai pegangan penanggulangan kwalitas pembelajaran dan 4) bagi pendidikan secara umum akan dapat dipakai sebagai pegangan untuk meningkatkan prestasi belajar. 
Prestasi belajar menurut Kamus Besar Bahasa Indonesia (2015: 895) berarti : a) penguasaan pengetahuan atau keterampilan yang dikembangkan oleh mata pelajaran, lazimnya ditunjukkan dengan nilai tes atau angka nilai yang diberikan guru, b) kemampuan yang sungguh-sungguh ada atau dapat diamati (actual ability) dan yang dapat diukur langsung dengan tes tertentu.

Prestasi belajar atau hasil belajar adalah realisasi atau pemekaran dari kecakapan potensial atau kapasitas yang dimiliki seseorang. Penguasaan prestasinya bila dilihat dari perilakunya, baik dalam bentuk perilaku penguasaan pengetahuan keterampilan berfikir maupun kemampuan motorik (Sukmadinata, 2015). Ada dua pendekatan didalam pelaksanaan pengajaran disekolah yaitu pendekatan yang mengutamakan hasil belajar dan menekankan proses belajar. Sesungguhnya di antara kedua pendekatan tersebut tidak terdapat perbedaan, sebab suatu hasil belajar yang baik akan diperoleh melalui proses yang baik pula (Sukmadinata, 2015).

Menurut Poerwadarminto (2011) prestasi belajar adalah hasil yang telah dicapai dari hasil pekerjaan yang menyenangkan hati yang diperoleh dengan keuletan kerja. Sedangkan menurut S. Nastion (2011) prestasi belajar merupakan petunjuk bagi siswa tentang kemampuannya dalam menguasai materi pembelajaran yang telah dicapai berupa hasil belajar.

Dari pendapat para ahli diatas dapat disimpulkan bahwa prestasi belajar adalah perubahan tingkah laku mencakup tiga aspek (kognitif, afektif dan motorik) seperti penguasaan, penggunaan dan penilaian berbagai pengetahuan dan ketrampilan sebagai akibat atau hasil dari proses belajar dengan faktor-faktor yang mempengaruhinya yang tertuang dalam bentuk nilai yang di berikan oleh guru.

Dimyati \& Mudjiono (2012: 42) mengemukakan prinsip-prinsip belajar adalah sebagai berikut: a) Perhatian dan motivasi, b) Keaktifan, c) Keterlibatan langsung, d) Balikan dan penguatan, e) Perbedaan individual

Arthur Combs (1981) memerinci kebutuhan akan tujuan pembelajaran (dalam Djiwandono, 2013: 181-182) dari sudut pandang pendidikan humanistik (membuat belajar dan mengajar lebih manusiawi, lebih personal, dan berarti) adalah sebagai berikut: 1) Menerima kebutuhan-kebutuhan dan tujuan siswa serta menciptakan pengalaman dan program untuk perkembangan keunikan potensi siswa. 2) Memudahkan aktualisasi diri siswa dan perasaan diri mampu. 3) Memperkuat perolehan keterampilan dasar (akademik, pribadi, antarpribadi, komunikasi dan ekonomi). 4) Memutuskan pendidikan secara pribadi dan penerapannya. 5) Mengenal pentingnya perasaan manusia, nilai, dan persepsi dalam proses pendidikan. 6) Mengembangkan suasana belajar yang menantang dan bisa dimengerti, mendukung, menyenangkan, serta bebas dari ancaman. 7) Mengembangkan siswa masalah ketulusan, respek, dan menghargai orang lain, dan terampil dalam menyelesaikan konflik.

Dari beberapa pengertian belajar tersebut di atas, kata kunci dari belajar adalah perubahan perilaku. Moh. Surya (2013) mengemukakan ciri-ciri dari perubahan perilaku, yaitu: 1) Perubahan yang disadari dan disengaja (intensional); Perubahan perilaku yang terjadi merupakan usaha sadar dan disengaja dari individu yang bersangkutan. 2) Perubahan yang berkesinambungan (kontinyu); Bertambahnya pengetahuan atau keterampilan yang dimiliki pada dasarnya merupakan kelanjutan dari pengetahuan dan keterampilan yang telah diperoleh sebelumnya. 3) Perubahan yang fungsional; Setiap perubahan perilaku yang terjadi dapat dimanfaatkan untuk kepentingan hidup individu yang bersangkutan, baik untuk kepentingan masa sekarang maupun masa mendatang. 4) Perubahan yang bersifat positif; Perubahan perilaku yang terjadi bersifat normatif dan menunjukkan ke arah kemajuan. 5) Perubahan yang bersifat aktif; Untuk memperoleh perilaku yang baru, individu yang bersangkutan aktif berupaya melakukan perubahan. 6) Perubahan yang bersifat permanen; Perubahan perilaku 
yang diperoleh dari proses belajar cenderung menetap dan menjadi bagian yang melekat dalam dirinya. 7) Perubahan yang bertujuan dan terarah; Individu melakukan kegiatan belajar pasti ada tujuan yang ingin dicapai, baik tujuan jangka pendek, jangka menengah maupun jangka panjang. 8) Perubahan perilaku secara keseluruhan; Perubahan perilaku belajar bukan hanya sekedar memperoleh pengetahuan semata, tetapi termasuk memperoleh pula perubahan dalam sikap dan keterampilannya.

Dari pendapat di atas dapat disimpulkan bahwa ciri-ciri belajar adalah perubahan secara sadar yang meliputi seluruh aspek tingkah laku ke arah yang lebih baik, belajar sebagai hasil dari latihan dan pengalaman serta perubahan yang terjadi relatif menetap.

Dimyati (2012) (dikutif dari Bhakti, 2013: 36) menyatakan bahwa prestasi belajar dipengaruhi oleh faktor intern dan faktor ekstern. Faktor intern yang dialami dan dihayati siswa yang berpengaruh terhadap proses belajar adalah: a). sikap siswa terhadap proses belajar, 2) motivasi belajar, 3) konsentrasi belajar, 4) kemampuan mengolah bahan ajar, 5) kemampuan menyimpan perolehan hasil belajar, 6) kemampuan menggali hasil belajar yang telah disimpan, 7) kemampuan untuk berprestasi atau unjuk hasil belajar, 8) rasa percaya diri siswa, intelegensi,keberhasilan belajar dan kebiasaan belajar. Faktor ekster yang mempengaruhi prestasi belajar antara lain: 1) guru sebagai pembimbing belajar siswa, 2) sarana dan prasarana belajar, 3) kondisi pembelajaran, 4) kebijaksanaan penilaian, 5) kurikulum yang diterapkan dan lingkungan sosial siswa.

Surya Mohamad (2013:28) mengatakan bahwa ciri kelas yang melaksanakan pembelajaran adalah: 1) siswa secara aktif terlibat dalam pembelajaran, 2) siswa belajar dari temannya melalui kerja kelompok, diskusi, saling mengkoreksi, 3) pembelajaran menekankan pada masalah bersifat terbuka, 4) prilaku siswa dibangun atas kesadaran diri dan hadiah untuk prilaku baik adalah kepuasan diri, 5) siswa menggunakan kemampuan berpikir kritis dan kreatif terlibat penuh dan ikut bertanggung jawab dalam mengayakan terjadinya proses pembelajaran yang efektif, 6) penghargaan terhadap pengakuan siswa sangat diharapkan.

Heller, Keith dan Andreson (dalam Wardani, 2011: 60) menyebutkan bahwa langkahlangkah dalam memecahkan masalah adalah: 1) visualisasi masalah yaitu dengan mengidentifikasi pendekatan umum terhadap masalah, yakni konsep dan prinsip fisika yang paling tepat untuk masalah tersebut, 2) menDeskripsikan masalah dan Deskripsi fisika yaitu dengan menandai secara simbolik variabel yang diketahui dan tidak diketahui yang kemudian menyatakan prinsip dan hubungan kuantitatif yang bersifat umum, 3) merencanakan solusi yang melibatkan siswa menterjemahkan Deskripsi fisika ke dalam represtasi matematis yang tepat, 4) menyelesaikan rencana yakni siswa diharapkan dapat menghitung variabel target dengan mensubstitusikan nilai yang diberikan, 5) menilai atau mengevaluasi jawaban yaitu siswa hendaknya menanyakan kembali apakah jawaban diperoleh sudah benar dan lengkap. Pelaksanaan pembelajaran ini haruslah didukung dengan segala sesuatu yang menyentuh kebutuhan siswa untuk dapat menggali berbagai informasi yang sesuai dan diperlukan dalam memecahkan masalah, misalnya laboratorium, perpustakaan, LKS dan media pembelajaran yang relevan. Melalui langkah pembelajaran yang diungkapkan di atas, siswa dilatih mengembangkan kompetensi penalaran sehingga daya nalar dan kreativitas berpikir dapat berkembang yang pada akhirnya mereka berlatih berfikir secara logis, kritis dan kreatif. Dalam buku Evaluasi Pendidikan (Depdiknas, 2015: Modul 3: 13) pemecahan masalah merupakan bagian dari Kurikulum Matematika yang sangat penting karena dalam proses pembelajaran maupun penyelesaiannya, siswa dimungkinkan memperoleh pengalaman menggunakan pengetahuan serta keterampilan yang sudah dimiliki untuk diterapkan pada pemecahan masalah yang bersifat tidak rutin. Melalui kegiatan ini aspek-aspek kemampuan matematika yang penting seperti penerapan aturan pada masalah tidak rutin, penemuan pola, 
penggeneralisasian, komunikasi matematika dan lain-lain dapat dikembangkan secara lebih baik.

Lebih lanjut dijelaskan bahwa tujuan diberikan pelajaran matematika adalah agar siswa mampu menghadapi perubahan-perubahan keadaan yang selalu berkembang melalui latihan bertindak atas dasar pemikiran logis, rasional, kritis, cermat, jujur dan efektif. Pelajaran diutamakan yang bersifat riil atau alamiah, dengan tema-tema permasalahan yang diambil dari kejadian sehari-hari yang dekat dengan kehidupan siswa. Selain itu, proses pemecahan masalah sebaiknya dilakukan dalam kelompok-kelompok kecil, sehingga mamberi peluang untuk berdiskusi dan saling bertukar pendapat yang dapat mengembangkan kemampuan berkomunikasi.

Uraian di atas didasari asas pemikiran Gagne, 1970 (dalam Depdiknas, 2015 Modul 3: 13-14) yang mengatakan bahwa keterampilan intelektual tingkat tinggi dapat dikembangkan melalui pemecahan masalah.

Kemampuan manusia berpikir ilmiah merupakan alat yang membantu kegiatan ilmiah dalam berbagai langkah yang harus ditempuh. Pada langkah tertentu biasanya juga diperlukan sarana tertentu pula. Tanpa penguasaan sarana berpikir ilmiah akan sulit melaksanakan kegiatan berpikir yang lebih tajam untuk bisa melaksanakan berpikir ilmiah dengan baik diperlukan sarana berpikir seperti kemampuan bahasa, logika.

Sizer (dalam Elaine B. Johnson, 2012) memberi pernyataan bahwa sekolah belajar menggunakan pikiran dengan baik, berpikir kreatif dalam menghadapi persoalan serta menanamkan kebiasaan untuk berpikir. John Dewey (dalam Elaine B. Johnson, 2012) mengatakan bahwa sekolah harus menganjurkan cara berpikir yang benar pada anak-anak. Dari kedua pernyataan tersebut untuk tingkat kemampuan berpikir mesti diupayakan agar tingkat berpikir tinggi dapat diharapkan.

Liasari, 20002 (dalam Wardani, 2011: 25) mengatakan ada 2 jenis kemampuan berpikir yaitu: berpikir dasar dan berpikir tingkat tinggi. Konsep tentang pemikiran tingkat tinggi diperoleh dari Tayonomy of Educational Objectives, Handbook I: Cognitive Domain oleh Bloom et.al. (dalam Anna \& Bryan, 2015). Konsep ini lebih dikenal sebagai Taksonomi Bloom, dimana sistem ini mengidentifikasi suatu kemajuan secara hirarkis untuk menggolongkan proses berpikir dari tingkat rendah ke tingkat yang lebih tinggi.

Model Problem Solving lebih banyak berpenekanan pada kemampuan berpikir tingkat tinggi. Untuk bisa melakukan ini maka diperlukan kecerdasan yang baik. Dalam hubungan matematika, karakteristik kecerdasan matematika yang dikemukakan oleh Judith Jewell (dialihbahasakan oleh Alexander Sindoro, 2013: 19) adalah pandai memecahkan tekateki angka dan soal abstrak, memahami statistik yang diterbitkan dalam berita dan tahu kalau bisa menyesatkan, senang mengetahui cara kerja berbagai peralatan, dan tahu cara membetulkan peralatan yang rusak, sering membuat daftar tugas yang diberi nomor. Dalam hubungan dengan tingkat berpikir tinggi, penulis coba hubungkan dengan pemahaman konsep dan berpikir formal. Pemahaman konsep seperti dikemukakan oleh Gagne (dalam Ratna Wilis Dahar, 2014: 85-86) yang merupakan prosedur bentuk belajar pemecahan masalah adalah menggabungkan aturan-aturan untuk mencapai suatu pemecahan yang menghasilkan sesuatu aturan dengan tingkat lebih tinggi. Apabila dihubungkan dengan tingkat berpikir formal, maka para siswa yang mampu berpikir tingkat tinggi akan mampu melakukan pengaturan sendiri dan keseimbangan. Pengaturan sendiri atau iquilibrasi menurut Piaget (dalam Ratna Wilis Dahar, 2014: 158) adalah kemampuan untuk mencapai kembali keseimbangan (equilibrium) selama periode ketidakseimbangan (disequilibrium). Equilibrasi merupakan suatu proses untuk mencapai tingkat-tingkat berfungsi kognitif yang lebih tinggi melalui asimilasi dan akomodasi, tingkat demi tingkat. 
Dari semua pendapat yang sudah disajikan di atas, untuk sementara dapat disampaikan bahwa model pembelajaran Problem Solving atau model pemecahan masalah pengupayakan agar siswa dapat melakukan pembelajaran dengan tidak menghafal, tetapi melakukan pembelajaran dengan mengupayakan agar mereka bisa berpikir logis, rasional, kritis, cermat, jujur dan efektif. Disamping itu mampu memecahkan masalah yang sedang dihadapi dengan memahami masalah tersebut, membuat perencanaan pemecahannya, menyelesaikan masalah tersebut dengan mengecek kembali langkah-langkah yang bisa diupayakan untuk itu. Siswa mesti diupayakan untuk mampu menggunakan proses berpikir yang lebih jauh dan lebih dalam, terlibat lebih aktif seperti berdiskusi, berprestasi, saling mengoreksi serta pemberian hadiah oleh guru bagi yang berprestasi. Guru mesti berupaya pada model pembelajaran ini dengan mengupayakan proses pemecahan masalah melalui kelompok-kelompok kecil yang akan memberi kesempatan atau peluang bagi para siswa untuk lebih banyak bertukar pikiran, bertukar pendapat untuk pencapaian keberhasilan yang lebih baik.

\section{METODE PENELITIAN}

Penelitian berlokasi di SMP Widya Sakti Denpasar kelas VIII A semester I Tahun Pelajaran 2019/2020, sekolah ini beralamat di Jl. Trenggana No.8 Penatih Denpasar Timur, Kota Denpasar Telp. (0361) 462586. Lingkungan sekolah ini sejuk dan rindang karena banyak pohon yang tumbuh dihalaman sekolah, bersih karena didepan masing-masing ruangan dan kelas disediakan tempat sampah. Rancangan merukan hal yang vital dalam sebuah penelitian. Untuk penelitian ini penulis memilih rancangan penelitian tindakan yang disampaikan oleh Elliot.

Dalam penelitian ini, peneliti memilih objek siswa SMP Widya Sakti Denpasar Kelas VIII A yang berjumlah 39 orang siswa. Untuk objek penelitian, digunakan penilaian peningkatan prestasi belajar siswa dengan tes. Yang menjadi subjek penelitian ini adalah siswa pada kelas VIII A SMP Widya Sakti Denpasar yang belajar pada semester I Tahun Pelajaran 2019/2020 dari bulan Juli s/d Nopember tahun 2019. Tes prestasi belajar merupakan metode pengumpulan data ini. Dengan menggunakan metode deskriptif untuk penelitian ini, sedangkan untuk data kuantitatif dianalisis dengan mencari mean, median, modus, membuat interval kelas dan melakukan penyajian dalam bentuk tabel dan grafik

\section{HASIL DAN PEMBAHASAN}

Gambaran hasil yang diperoleh pada kegiatan awal yaitu 4 orang siswa $(10,26 \%)$ memperoleh nilai di atas KKM, 11 orang siswa $(28,21 \%)$ memperoleh nilai sama dengan KKM dan sisanya sebanyak 24 orang siswa $(61,54 \%)$ memperoleh nilai di bawah KKM. Hasil ini sangat jauh dari KKM mata pelajaran matematika yaitu 75,00 karena baru tercapai nilai rata-rata sebesar 70,97 .

Perolehan hasil dari penilaian yang telah dilakukan dapat diberi deskripsi: dari 39 siswa ada $15(38,45 \%)$ siswa yang memperoleh penilaian di atas KKM, 15 siswa $(38,45 \%)$ memperoleh nilai sama dengan KKM. Walaupun demikian masih ada 9 siswa $(23,08 \%)$ yang belum mencapai KKM. Data tersebut menunjukkan bahwa perolehan perkembangan siswa belum sesuai indikator keberhasilan penelitian.

Analisis kuantitatifnya menggunakan data yang diperoleh adalah dalam bentuk angka sebagai berikut: 1) Rata-rata (mean) dihitung dengan: (Jumlah nilai)/(Jumlah siswa) = $(2.916) / 39=74,77 ; 2)$ Median (titik tengahnya) dicari dengan mengurut data/nilai siswa dari yang terkecil sampai terbesar. Setelah diurut apabila jumlah data ganjil maka mediannya 
adalah data yang ditengah. Kalau jumlahnya genap maka dua data yang di tengah dijumlahkan dibagi 2 (dua). Untuk median yang diperoleh dari data siklus I dengan menggunakan cara tersebut adalah: 75,00; 3) Modus (angka yang paling banyak/paling sering muncul) setelah diasccending/diurut. Angka tersebut adalah: 75,00

Tabel 1. Data Kelas Interval Siklus I

\begin{tabular}{ccccc}
\hline $\begin{array}{c}\text { No } \\
\text { Urut }\end{array}$ & Interval & $\begin{array}{c}\text { Nilai } \\
\text { Tengah }\end{array}$ & $\begin{array}{c}\text { Frekuensi } \\
\text { Absolut }\end{array}$ & $\begin{array}{c}\text { Frekuensi } \\
\text { Relatif }\end{array}$ \\
\hline 1 & $65-67$ & 66 & 3 & 7,69 \\
2 & $68-70$ & 69 & 6 & 15,38 \\
3 & $71-73$ & 72 & 0 & 0,00 \\
4 & $74-76$ & 75 & 15 & 38,46 \\
5 & $77-79$ & 78 & 12 & 30,77 \\
6 & $80-82$ & 81 & 3 & 7,69 \\
\hline \multicolumn{6}{c}{ Total } & & 39 & 100 \\
\hline
\end{tabular}

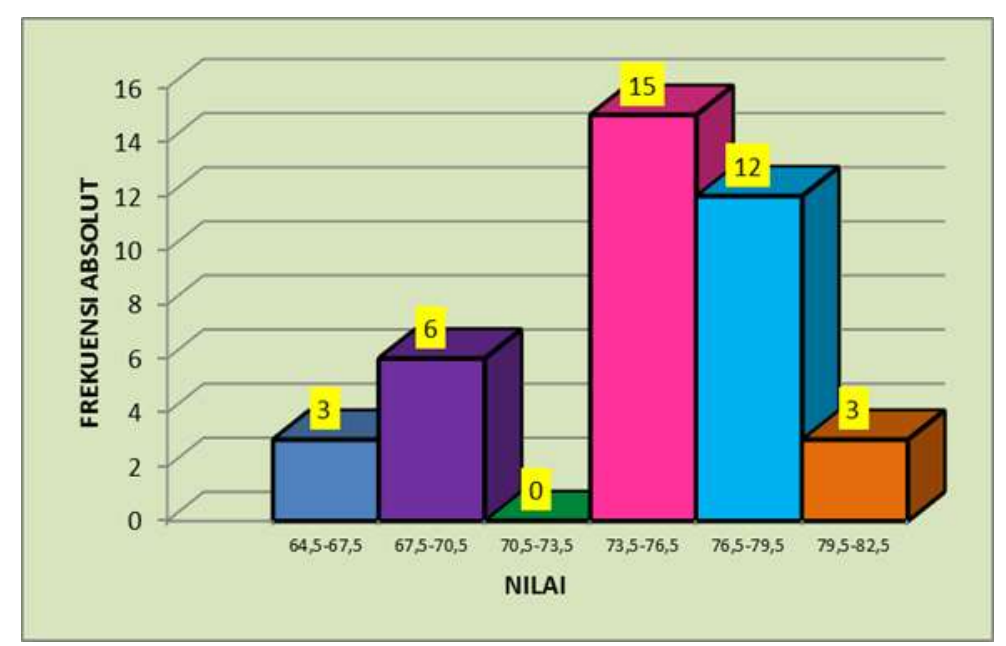

Gambar 1. Histogram Siklus I

Pada siklus II secara kualitatif hasil yang diperoleh dapat dijelaskan dari 39 siswa yang diteliti ada $35(89,74 \%)$ siswa yang mendapat nilai diatas KKM artinya mereka sudah mampu menguasai materi-materi yang diberikan dan mereka sudah berkembang sangat baik melebihi indikator yang dituntut. 4 siswa $(10,26 \%)$ memperoleh nilai sama dengan KKM.

Tabel 2. Data Kelas Interval Siklus II

\begin{tabular}{ccccc}
\hline $\begin{array}{c}\text { No } \\
\text { Urut }\end{array}$ & Interval & $\begin{array}{c}\text { Nilai } \\
\text { Tengah }\end{array}$ & $\begin{array}{c}\text { Frekuensi } \\
\text { Absolut }\end{array}$ & $\begin{array}{c}\text { Frekuensi } \\
\text { Relatif }\end{array}$ \\
\hline 1 & $75-77$ & 76 & 4 & 10,26 \\
2 & $78-80$ & 79 & 15 & 38,46 \\
3 & $81-83$ & 82 & 6 & 15,38 \\
4 & $84-86$ & 85 & 12 & 30,77 \\
5 & $87-89$ & 88 & 2 & 5,13 \\
6 & $90-92$ & 91 & 0 & 0,00 \\
\hline Total & & & 39 & 100,00 \\
\hline
\end{tabular}




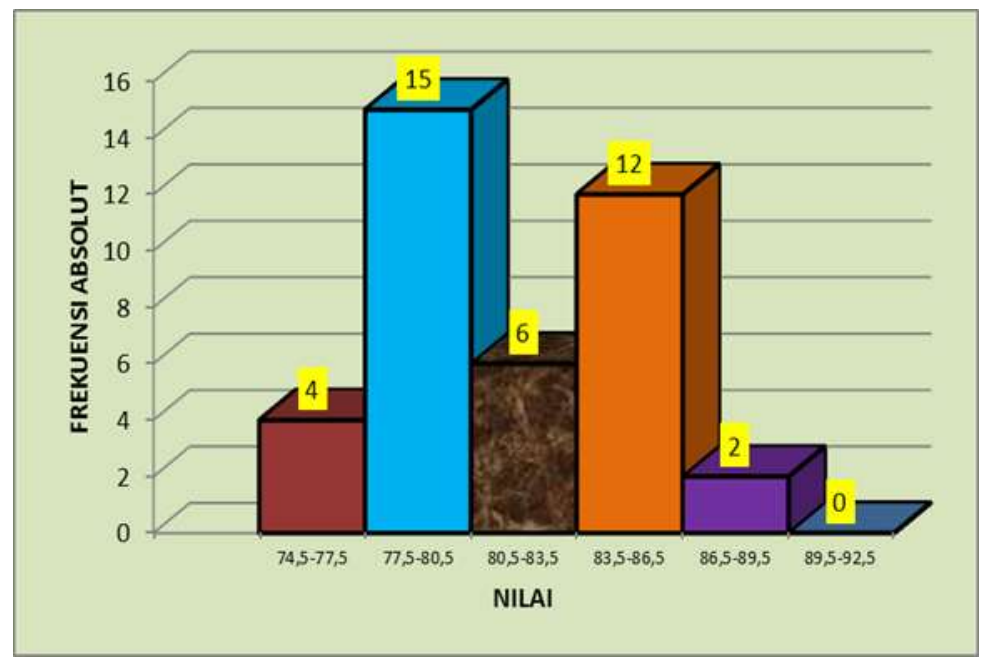

Gambar 2. Histogram Siklus II

Peningkatan prestasi belajar pada siklus II ini adalah 39 siswa yang diteliti ternyata hasilnya sudah sesuai dengan harapan, dimana peserta didik memperoleh nilai rata-rata 81,46 sedangkan prosentase ketuntasan belajarnya sudah mencapai $100 \%$ dan sudah melebihi prosentase yang dipersyaratkan yaitu $85,00 \%$ atau lebih. Dari perkembangan tersebut diketahui hampir semua siswa sudah sangat mampu meningkatkan prestasi belajarnya. Dari semua data yang sudah diperoleh tersebut dapat diberikan sintesis bahwa keberhasilan sudah dapat dicapai, hal tersebut berarti indikator yang diharapkan dicapai oleh siswa SMP Widya Sakti Denpasar sudah tercapai

\section{KESIMPULAN DAN SARAN}

Perolehan data awal yang rendah dan belum mencapai nilai kriteria ketuntasan minimal sesuai harapan, membuat peneliti harus giat mengupayakan cara agar masalah pembelajaran yang ada dapat diperbaiki sehingga peningkatan kemampuan peserta didik dalam menempa ilmu pengetahuan dapat meningkat sesuai harapan. Setelah dilakukan penggantian model pembelajaran dari model pembelajaran yang konvensional menjadi model pembelajaran yang konstruktivis yaitu model pembelajaran Problem Solving ternyata hasil yang diperoleh meningkat dari data awal 70,97 menjadi 74,77 pada siklus I. Setelah perlakuan tindakan dilakukan dengan cukup intentis maka hasil yang diperoleh pada siklus II naik menjadi 81,46 dan mencapai rata-rata sesuai kriteria ketuntasan minimal yang diharapkan. Dengan terjadinya kenaikan prestasi belajar sesuai harapan maka dapat disampaikan bahwa rumusan masalah dan tujuan penelitian sudah mampu tercapai. Dari perolehan bukti tersebut dapat disimpulkan juga bahwa hipotesis penelitian yang diajukan sudah dapat diterima.Jadi dapat disimpulkan prestasi belajar matematika dapat ditingkatkan dengan mengoptimalkan model pembelajaran problem solving pada siswa kelas VIII A semester I SMP Widya Sakti Denpasar tahun pelajaran 2019/2020.

Sesuai dengan simpulan dari hasil penelitian, dalam upaya mencapai tujuan pembelajaran Matematika, dapat disampaikan saran-saran sebagai berikut: 1) Kepada teman guru pengajar mata pelajaran matematika disarankan mencoba model pembelajaran Problem Solving. 2) Kepada Kepala Sekolah disarankan untuk untuk memberi penekanan agar guru mau melaksanakan pembelajaran dengan langkah-langkah model yang sudah diteliti. 3) Dalam melaksanakan proses pembelajaran pada mata pelajaran matematika penggunaan model Problem Solving semestinya menjadi pilihan dari beberapa model yang ada mengingat model ini telah terbukti dapat meningkatkan kerjasama, berkreasi, bertindak aktif, bertukar 
informasi, mengeluarkan pendapat, bertanya, berdiskusi, berargumentasi dan lain-lain. 4) Walaupun penelitian ini sudah dapat membuktikan efek utama dari model Problem Solving dalam meningkatkan prestasi belajar, sudah pasti dalam penelitian ini masih ada hal-hal yang belum sempurna dilakukan, oleh karenanya kepada peneliti lain yang berminat meneliti topik yang sama untuk meneliti bagian-bagian yang tidak sempat diteliti. 5) Demi kesempurnaan penelitiaan ini, peneliti mengharapkan kritik, saran, masukan yang konstruktif sehingga diharapkan bagi peneliti lain untuk melakukan penelitian lanjutan

\section{UCAPAN TERIMAKASIH}

Ucapan terima kasih disampaikan kepada Bapak Kepala Bidang Pembinaan Sekolah Menengah Pertama (Drs. A.A. Gde Agung Wiratama, M.Ag) dan Bapak/Ibu Guru SMP Widya Sakti Denpasar

\section{DAFTAR PUSTAKA}

Alexander Sindoro, Enjang. 2013. Komunikasi Konseling. Bandung: Nuansa Cendekia. Anna \& Bryan. 2015. Contructism A Theory of Knowledge. Purdue University. Journal of Chemical Education. Vol. 63. no. 10

Arikunto, Suharsimi; Suhardjono; Supardi. 2006. Penelitian Tindakan Kelas. Jakarta: PT Bumi Aksara.

Bhakti, Ahmad Haris. 2013. Tesis. Pengaruh Strategi Pembelajaran Kooperatif Tipe STAD (Student Team Achievement Division) Dan Jigsaw Terhadap Prestasi Belajar Pendidikan Kewarganegaraan Ditinjau Dari Minat Belajar Siswa SMP Negeri Di Kecamatan Ngawi. Program Studi Teknologi Pendidikan. Program Pascasarjana Universitas Sebelas Maret. Surakarta.

Dahar, Ratna Wilis. 2014. Teori-Teori Belajar. Jakarta: Penerbit Erlangga.

Depdiknas. 2015. Modul 3. Evaluasi Pendidikan. Jakarta: Balai Pustaka.

Dimyati \& Mudjiono. (2012). Belajar dan Pembelajaran. Jakarta: Rineka Cipta

Djamarah, Syaful Bahri. 2002. Prestasi Belajar dan Kompetensi Guru. Surabaya: Usaha Nasional.

Djiwandono, Sri Esti Wuryani. 2013. Psikologi Pendidikan (Rev-2). Penerbit: Grasindo. Jakarta.

Johnson and R.T. Johnson. 2012. Learning Together and Alone: Cooperation, Competition, and Individualistic Learning. Englewood Cliffs, N.J.: Prentice-Hall.

Kunandar. 2008. Langkah Mudah Penelitian Tindakan Kelas Sebagai Pengembangan Profesi Guru. Jakarta: Rajawali Pers.

Modern Educators and Lexicographers. 1939. Webster's New American Detionary. New York: 140 Broadway, Books, Inc.

Mohamad Surya. (2013). Dalam Proses Belajar Mengajar. Bandung: PT Remaja Rosda Karya.

Nasution, S. 2011. Berbagai Pendekatan Dalam Proses Belajar dan Mengajar. Jakarta : Bumikarsa.

Purwanto, Ngalim. 1997. Psikologi Pendidikan. Bandung: Rosdakarya.

Prayitno. 2009. Dasar Teori dan Praksis Pendidikan. Penerbit: Grasindo. Jakarta.

Sardiman, A.M. 1988. Interaksi dan Motivasi Belajar-Mengajar Pedoman bagi Guru dan Calon Guru. Jakarta: Rajawali Pers.

Soejono dan H. Abdurrahman. 2003. Metode Penelitian Hukum. Jakarta: PT Rineka Cipta. 
Sriyono. 1992. http://www.scribd.com/doc/9037208/

Sukmadinata, Nana Syaodih. 2015. Landasan Psikologi Proses Pendidikan. Bandung: Remaja Rosda Karya.

Suhardjono. 2010. Pertanyaan dan Jawaban di Sekitar Penelitian Tindakan Kelas dan Penelitian Tindakan Sekolah. Malang: Cakrawala Indonesia.

Tim Penyusun Kamus Pusat Bahasa Indonesia. (2015). Kamus Besar Bahasa Indonesia Edisi Ketiga. Jakarta: Balai Pustaka

Wardani, Dyah Retno Kusuma. 2011. Pengaruh Metode Pembelajaran Problem Solving ddan Group Investigation terhadap Keterampilan Berpikir Tingkat Tinggi dengan Mempertimbangkan Kreativitas pada Siswa Kelas VIII SMP Negeri 3 Denpasar Tahun Ajaran 2010/2011. Tesis. Universitas Pendidikan Ganesha Program Pascasarjana Singaraja 